\title{
MANIPOL USDEK SEBAGAI TANTANGAN PENDIDIKAN PADA JAMAN REFORMASI BAGI GENERASI PENERUS BANGSA
}

\author{
Oleh \\ I Made Arka \\ Anak Agung Ngurah Agung Wira Bima Wikrama \\ Fakultas Ilmu Sosial dan Ilmu Politik Universitas Mahendradatta \\ Email: imdarka73@gmail.com | bimawikrama65@gmail.com
}

\begin{abstract}
Abstrak - Manipol USDEK adalah Manisfesto Politik dari Presiden Soekarno atas keadaan Bangsa Indonesia yang terjadi pada 5 Juli 1959 terkait pertanggunjawaban presiden yang isinya yaitu: 1) Undang - Undang Dasar 1945, 2) Sosialisme Indonesia, 3) Demokrasi Terpimpin, 4) Ekonomi Terpimpin, 5) Kepribadian Bangsa Indonesia. Manipol USDEK dapat dikaitkan dalam situasi pendidikan pada jaman reformasi untuk mendapatkan jalan keluar permasalah bangsa dalam memajukan rakyat Indonesia menjadi masyarakat yang cerdas, berbudi pekerti, dan mempunyai karakter nasionalisme dalam membangun Negara Kesatuan Republik Indonesia. Dalam perjalanan Bangsa Indonesia yang dari negara terjajah sampai menjadi negara berkembang dan menuju negara maju perlu diulas kembali maksud dan tujuan dari pertanggungjawaban Presiden Soekarno agar masyarakat tahu sejarah bangsa Indonesia dalam menjalankan roda kepemerintahan. Pada jaman reformasi ini perkembangan teknologi sangat pesat maka perlu diselaraskan antara konsep yang disiapkan dan konsep tindaklajut keadaan perkembangan situasi bangsa agar jangan masyarakat hanya terpaku dalam kejadian masa lalu yang mengakibatkan bangsa ini menjadi paranoid terhadap perkembangan jaman. Maka hanya melalui pendidikan rakyat Indonesia bisa membangun bangsa ini lebih baik dan bisa bersaing di kancah internasional jika pendidikan yang tepat dapat diberikan kepada generasi penerus bangsa.
\end{abstract}

Kata kunci: tantangan, pendidikan, reformasi

\section{PENDAHULUAN}

Manipol USDEK adalah bentuk pertanggungjawaban Presiden Soekarno atas dekrit yang dikeluarkan pada 5 Juli 1959 (Manifesto Politik) dan inti sari dari pertanggungjawaban presiden tersebut adalah: 1) Undang - Undang Dasar 1945, 2)
Sosialisme Indonesia, 3) Demokrasi Terpimpin, 4) Ekonomi Terpimpin, 5) Kepribadian Bangsa Indonesia. Konsep ini disampaikan dalam pidato beliau yang berjudul "Penemuan Kembali Revolusi Kita" dan kemudian dikenal sebagai Manifesto Politik. Pidato ini disampaikan 
pada saat pelaksanaan upacara bendera 17 Agustus 1959. Pada tahun 1960, DPAS mengusulkan ke pemerintah agar Manifesto Politik dijadikan sebuah ketetapan. MPRS kemudian menetapkan Manifesto Politik sebagai GBHN (Garis Besar Haluan Negara) melalui Tap MPRS No 1/1960. Sesuai dengan konsep yang disampaikan oleh Bung Karno, mulailah muncul konsep Garis-garis Besar Haluan Negara yang di terapkan pada jaman Orde Baru dan seakan memaksa masyarakat harus mengerti apa yang disebutkan oleh Bung Karno.

Melalui konsep yang disampaikan sejak awal bahwa Negara Indonesia ini membutuhkan kerangka berpikir dalam mensukseskan kehidupan berbangsa dan bernegara. Akan tetapi masih banyak ada tantangan yang dihadapi Bangsa Indonesia sehingga harus membutuhkan kesadaran masayarakat untuk menjadikan masyarakat Indonesia mempunyai keteguhan hati nasionalisme dengan karakter dan budaya yang berbeda. Berbicara masalah tersebut peran utama dalam mensukseskan masyarakat Indonesia dalam menjadi bangsa yang kuat adalah pendidikan. Pun di dalam sastra Hindu juga disampaikan bahwa Yadnya yang tertinggi adalah pendidikan. Maka oleh karena itu pendidikan adalah peran yang utama harus dilakukan dalam mengembangkan masyarakat Indonesia menuju Masyarakat yang madani. Madani artinya masyarakat sudah mampu memenuhi kebutuhan dan kemampuan pendidikan dalam mengembangkan sumber daya manusia yang unggul.

Yang menjadi pertanyaan adalah apakah Bangsa Indonesia ini sudah bisa bersaing dalam menghadapi kehidupan yang globalisme ini dengan keterbasan yang dimiliki oleh negara kita dalam bidang pendidikan. Tentu menjadi pembicaraan yang pro dan kontra dalam menyikapi permasalahan yang dihadapi masyarakat di lapangan terkait dengan hiruk pikuknya pendidikan yang menjadi viral dalam pembahasan di media sosial ketika berbicara tentang penggunaan media daring dalam pembelajaran di masa pademi covid 19 ini. Di samping juga ketersediaan media yang digunakan untuk pembelajaraan yang menjadi peran utamanya antara lain: a) tidak semua siswa mempunyai Handphone, b) jaringan internet yang belum memadai di seluruh wilayah, c) biaya dalam penyediaan kuota, d) cara pemakaian daring belum maksimal, e) pengajar yang belum bisa mengoperaionalkan media dari, dan sebagainya. Terkait dengan hal tersebut di atas maka perlu pembahasan yang terperinci dalam menerapkan Manipol Usdek yag digagas oleh bung Karno dalam memajukan masyarakat Indonesia agar bisa bersaing dalam merebut kesempatan kerja bagi masyarakat Indonesia di seluruh dunia.

\section{HASIL PEMBAHASAN}

Sesuai dengan konsep yang disampaikan oleh Bung Karno Presiden RI yang pertama, ada hal-hal yang ingin beliau terapakan agar bangsa Indonesia menjadi bangsa yang besar dan beliau sering mengungkapkan beberapa slogan yaitu bangsa yang besar adalah bangsa yang menghagai sejarahnya, dan berikan kami 10 pemuda akan kami guncang dunia ini, serta perjuanganku akan lebih mudah melawan penjajah akan tetapi perjuanganya akan lebih sulit melawan bangsamu. Kata-kata penyemangat yang disampaikan oleh Bung Karno sampai hari inipun tetap menggugah 
hati rakyatnya agar tetap bangga menjadi orang Indonesia. SesuaI dengan konsep awal Manipol Usdek adalah Manifesto Politik Bung Karno dengan konsep USDEK yang berarti antara lain:

1. Undang - Undang Dasar 1945

2. Sosialisme Indonesia

3. Demokrasi Terpimpin

4. Ekonomi Terpimpin

5. Kepribadian Bangsa Indonesia

Dari uraian di atas maka perlu pemahaman yang sama antara pemimpin dengan masyarakatnya sehingga terjalin kerjasama yang baik dalam menjalankan kehidupan berbangsa dan bernegara. Halhal yang menjadi peratian dalam pembahasan adalah:

\subsection{Undang - Undang Dasar 1945}

Undang-Undang Dasar

1945

merupakan payung hukum yang paling dasar dari segala hukum yang berlaku di Negara Indonesia. Undang-Undang Dasar 1945 merupakan induk segala peraturan dan semua peraturan lain yang dikeluarkan oleh pemerintah tidak diperbolehkan bertentangan dengan Undang-Undang Dasar 1945. Ada 4 hal penting yang mengatur Undang-Undang Dasar 1945 yaitu: 1) Prinsip kedaulatan rakyat dan negara hukum, 2) Pembatasan kekuasaan organ-organ negara, 3) mengatur hubungan antar lembaga-lembaga negara, 4) mengatur hubungan kekuasaan antar lembagalembaga negara dengan warga negara. Jika ditelisik sejarah Undang-Undang Dasar maka perjalannya mengalami perubahan sebanyak 5 kali yaitu:

1. Pertama Undang-Undang Dasar 1945 pada tanggal 18 agustus 1945 sampai dengan 27 Desember 1949
2. Kedua Konstitusi RI Serikat 1949 pada tanggal 27 Desember 1945 sampai dengan 27 Agustus 1950

3. Ketiga Undang-Undang Dasar Sementara 1950 pada tanggal 17 Agustus 1950 sampai dengan 5 Juli 1959

4. Keempat Undang-Undang Dasar 1945 Dekrit Presiden 5 Juli 1959 sampai dengan tahun 1999

5. Kelima Undang-Undang Dasar NRI 1945 hasil perubahan

Demikian peliknya perubahan Undang-Undang Dasar sampai 5 kali oleh pemerintah agar mendapatkan formulasi yang tepat dengan keadaan Negara Kesatuan Republik Indonesia hingga sekarang akan tetapi masih juga ditemukan hal-hal yang kurang bagus dalam pengelolaan negara yang kita cintai. Sama halnya dengan Undang Undang Nomor 20 Tahun 2003 tentang sistem Pendidikan Nasional sudah sering kali pemerintah mengevaluasi dengan membuat Permendikbud demi memajukan pendidikan di Negara Indonesia akan tetapi masih juga banyak ditemukan permasalahan yang terjadi di dunia pendidikan. Seakan akan pergantian menteri juga pergantian aturan pendidikan dari yang namanya Ujian Nasional, tidak adanya Ujian Nasional dan sekarang menggunakan daring serta yang terakhir perdebatan mata pelajaran sejarah akan dihapus. Dari perubahan aturan tersebut semua institusi menginginkan yang terbaik dilakukan demi generasi penerus bangsa yang menjadi tulang punggung Negara Indonesia. Perubahan aturan tersebut diharapkan dapat menjadi cikal bakal pemuda Indonesia bisa bersaing di tingkat internasional bukan saja terkait dengan keilmuan tetapi prilaku bangsa kita 
yang sudah dikenal dengan bangsa yang bermartabat.

\subsection{Sosialisme Indonesia}

Sosialisme Indonesia adalah sebuah konsep pemerintah yang mewujudkan masyarakat mandiri dan madani secara ekonomi, mengedepankan budaya bangsa, serta berdaulat dalam berpolitik seperti Tri Sakti yang disampaikan oleh Bung Karno yaitu: 1) Berdaulat dalam Politik, 2) Berdikari di bidang Ekonomi, Berkepribadian dalam Kebudayaan. Sosialisme Indonesia juga merupakan konsep yang menekankan sebuah negara harus memiliki dasar yang kuat dengan diwujudkan kehidupan masyarakat luas yang makmur, sejahtera, dan berbudaya. Sosialisme Indonesia harus terus dijaga agar ada kerukunan dan saling empati terhadap sesama masyarakat Indonesia.

Disetiap daerah masyarakat Indonesia mempunyai adat dan budaya yang berbeda dan sudah dilakukan dengan caracara yang sangat lekat dalam berkehidupan masyarakat. Salah satu konsep yang ada di Pulau Bali dengan sebutan "Basudewa kutum bhakam" yang artinya kita semua bersaudara. Dengan mengatakan kita semua bersaudara bisa terjalin kehidupan yang bersosial demi tegaknya kerukunan di antara Suku, Ras, Budaya, Etnis dan Agama. Pesan yang ingin disampaikan kepada masyarakat Indonesia adalah dengan kita saling menghargai pendapat dan mendapatkan pendidikan karakter Bangsa Indonesia yang saling bahu membahu dalam membantu masyarakat yang mendapatkan musibah. Dengan demikian muncullah rasa sosialisme Indonesia dalam pembangunan Indonesia seutuhnya demi menjaga NKRI dari serangan perubahan dunia luar yang tidak bisa dibendung dan merusak karater Bangsa Indonesia.

\subsection{Demokrasi Terpimpin}

Demokrasi Terpimpin adalah mengedepankan fokus pemerintahan kepada pimpinan negara, yang pada saat itu adalah Pimpinan Besar Revolusi Presiden Soekarno. Hal ini dirasa perlu karena pada saat itu pihak - pihak yang ditugaskan untuk mencanangkan undang - undang baru pengganti UUD 1950 dinilai gagal. Presiden Soekarno menganjurkan agar UUD 1950 diganti dengan UUD 1945.

Permasalahannya adalah pergantian kabinet yang sangat cepat, sehingga tugas belum terselesaikanakan tetapi sudah diganti oleh orang lain yang belum tentu berpandangan sama. Akhirnya program pemerintah tidak bisa berjalan dengan baik. Di dalam kepemimpinan presiden harus terus fokus dalam menyelesaikan permaslahan bangsa walaupun ada banyak kritikan yang menghujat kepemimpinannya.

Resesi kepemimpinan sampai sekarang pun masih terjadi, kepuasan kepemimpinan pada jaman sekarang masih dirasakan timpang dan sangat berpihak kepada golongan, kelompok, saudara dan sebagainya. Pun pasti ada pemimpin yang berjalan tegak lurus walaupun sering dicibir oleh masyarakat yang menginginkan kemauannya harus terpenuhi. Dengan caracara seperti itu pemimpin seharusnya sudah berani melawan dan menolak kepemimpinan seperti itu dengan berani bicara dari hati nurani karena hidup bukanlah apa yang kita dapatkan tetapi sebagai seorang pemimpin harus berani dan berpikir apa yang bisa kita sumbangkan kepada bangsa dan negara kita. Cara kepemimpinan sekarang masih dalam 
keadaan pro dan kontra dimana pemimpin yang bersih dan berani berkorban serta berani bicara demi keadilan masyarakat masih menunaikan kritik seakan-akan disebutkan sok suci ataupun cari muka dihadapan masyarakat padahal perjuangan mereka betul-betul murni dalam memperjuangkan kepentingan masyarakat. Sifat-sifat pemimpin seperti ini harus terus dipertahankan agar bangsa dan negara Indonesia bisa menjadi negara yang berdaulat dan mampu bersaing dengan negara maju dengan konsep sila keempat Kerakyatan yang dipimpin oleh hikmat kebijaksaan dalam permusyawaratan/ perwakilan.

\subsection{Ekonomi Terpimpin}

Ekonomi Terpimpin adalah sistem ekonomi dalam keputusannya dipegang oleh pemerintah pusat. Pemerintah pusat berhak menentukan barang dan jasa yang boleh dan tidak boleh diproduksi dalam negaranya, diproduksi oleh siapa, metode produksinya, dan untuk siapa barang dan jasa itu diproduksi. Walaupun demikian di negara Indonesia masih banyak plagiat atau barang-barang yang diduplikasi oleh sebagian orang yang berbisnis gelap atau dalam istilah black market. Sekelumik masalah yang terjadi di lapangan dalam penyedian barang dan jasa sehingga Barang Indonesia sempat mengalami guncangan dari pasar Internasional yang menyampaikan barang tidak berkualitas. Bukan saja barang-barang elektronik menjadi incaran dari pengusaha nakal agar mendapat keuntungan yang berlipat tetapi kerajinan tangan pun mendapatkan tantangan dari pasar internasional yang dulunya mengatakan kerajinan tangan masyarakat Bali sangat menjaga kualitas akan tetapi karena persaingan yang sangat ketat makan pengusaha Bali akhirnya banyak yang sampai gulung tikar alias bangkrut. Menyikapi masalah tersebut peran pemerintah harus lebih inten melakukan penertiban terhadap kualitas barang yang diperdagangkan dan memberikan edukasi kepada pengusaha dengan melakukan seminar-seminar tentang kualitas barang dan jasa.

Fenomena pada jaman Jokowi sudah mulai berubah yang awalnya pengusaha besar menjadi dominan dalam berbisnis tetapi pada jaman digital ini pasaran sudah mulai berubah dengan seiring perkembangan malahan toko besar dan malmal mulai ditinggalkan oleh masyarakat dengan berbelanja on line serta usaha di jama pademi ini mulai bermunculan usaha mikro menengah kebawah. Dengan modal yang kecil masyarakat sudah bisa melakukan bisnis yang disebut dengan UKM (Usaha Kecil Menengah) dan pemerintah hadir dalam mensupport usahausaha mikro tersebut dengan memberikan bantuan tanpa anggunan sehingga menumbuhkan kembangkan masyarakat untuk berani buka usaha. Dengan seperti ini diharapkan pemerintah hadir dalam mensupport masyarakat untuk mau melakukan suatu usaha sehingga terbuka lapangan kerja yang memadai karena jumlah penduduk Indonesia sudah lebih dari 270 juta. Harapan masyarakat agar pemerintah selalu hadir ditengah-tengah masyarakat yang sedang menglami kesusahan. Seperti musim hujan berbulanbulan tetapi datang hujan sehari membuat keteduhan buat masyarakat.

2.5. Kepribadian Bangsa Indonesia 
Kepribadian Bangsa Indonesia adalah Pancasila. Konsep ini sangat luar biasa dalam perancangannya untuk membangun bangsa dan negara Indonesia yang kuat dan kokoh. Dalam perjalanannya banyak tantangan yang harus dihadapi termasuk dalam sila pertama ada beberapa usulan dan akhirnya diputuskan Ketuhanan Yang Maha Esa. Kepribadian Bangsa Indonesia sangatlah penting dipertahankan untuk menunjukan jati diri bangsa kita dalam menangkal semua jenis gempuran yang datang dari negara luar bukan hanya dari kebudayaan tetapi banyak hal yang harus perlu diwaspadai untuk menjaga Negara Kesatuan Republik Indonesia dari oknum-oknum yang ingin menjajah Indonesia kembali lagi. Pancasila adalah Dasar Negara Indonesia yang harus terus dijaga agar tidak menjadi rongrongan bangsa lain yang ingin merusak dan menghacurkan Indonesia. Dari kelima sila yang ada semua saling berkaitan dengan lainnya sehingga menjadi satu kesatuan dalam bebangsa dan bernegara. Pancasila bukan hanya sebagai lambang Negara Indonesia tapi juga sebagai guide line masyarakat Indonesia di dalam menjalankan semua aktivitas kehidupan.

Konsep the founding father Bapak Ir. Soekarno mencari dasar negara Indonesia tidaklah mudah dengan banayk membaca dan turun langsung ke masyarakat ditemukanlah Pancasila itu sebagai dasar Negara dan di dalam genggaman burung garuda ada pita yang bertulisan "Bhinneka Tunggal Ika" yang diambil dari kitab suci Agama Hindu yaitu Kitab Suci Sutasoma yang dikarang oleh Mpu Tantular dalam bahasa sansekerta mengatakan Bhinneka Tunggal Ika ten Hana Dharma Mangwa yang mempunyai arti berbeda-beda tetapi tetap satu jua dan tidak ada duanya dharma itu. Dengan konsep ini dan melihat kemajemukan masyarkat Indonesia cocoklah penyampaian $\mathrm{Mpu}$ Tantular bahwa walaupun kita berbeda tetapi kita punya satu tujuan yaitu membesarkan bangsa dan negara Indonesia menjadi negara yang kuat dan tangguh disegala bidang.

Pancasila dan Bhinneka Tunggal Ika menjadi satu kesatua dalam bingkai keragaman bangsa Indonesia dengan perbedaan Suku, Ras, Budaya, Adat dan Agama sehingga masyarkat Indonesia tidaklah mungkin memaksakan umatnya agar sama dalam pelaksanaannya di dalam bekehidupan berbangsa dan bernegara. Hal ini perlu terus disosialisasikan dalam kehidupan bermasyakarat agar anak cucu dan generasi penerus tahu terhadap sejarah bangsa Indonesia dan bisa mempertahankan kemajemukan dalam kehidupan sehari-hari sehingga terjadinya kerukunan dalam bermasyarakat. Akan tetapi tantangan yang dihadapi generasi penerus tidaklah mudah dengan jaman reformasi dan melinia ini banyak masyarakat Indonesia mengikuti budaya asing dan sering mengatakan bahwa kebudayaan yang mereka jalankan seakanakan lebih baik dibandingkan dengan budayanya sendiri. Bung karno pernah mengatakan dengan tegas bahwa ketika kita memeluk agama agar tetpat menjadi jati diri bangsa Indonesia. Pidato-pidatonya sering disampaikan seakan menggugah rasa nasionalisme bangsa Indonesia dan mengatakan ketika anda menganut agama Islam jangan menjadi Islam Arab, ketika anda menganut Agama Hindu jangan menjadi hindu India, dan jika anda menganut Kristen janganlah menjadi Kristen Yahudi. Pesan-pesan ini perlu 
disampaikan kepada generasi penerus agar terus ingat terhadap bangsanya sendiri dan bangga menjadi orang Indonesia.

Sesuai dengan uraian tersebut diatas maka Manipol Usdek dikaitkan dengan Pendidikan bagi generasi penerus Bangsa harus mulai sadar akan tantangan yang dimiliki ke depan agar bisa bersaing dan berjuang untuk melangsungkan kehidupan berbangsa dan bernegara. Pemuda bukan saja menjadi "Agent of Changes" tetapi Pemuda di jaman reformasi harus memiliki jiwa Nasionalis dan Kebangsaan yang menjadi pondasi Karakter dan Prilaku Bangsa Indonesia untuk menunjukan Bangsa Indonesia memiliki SDM yang bisa bersaing di kancah nasional maupun Internasional. Pemuda dan generasi penerus Bangsa Indonesia diharapkan menjadi garda terdepan seperti Pidato Bung Karno “ Berikan kami 10 Pemuda akan kami guncang Dunia ini”.

Dengan memahami Manipol Usdek sebenarnya Pemuda sebagai generasi penerus Bangsa bisa dan mampu mempunyai pedoman dalam hidupnya untuk mengerti tentang konsep pendirian Bangsa Indoensia dalam menunjukkan jati diri dan karakter Bangsa demi persaingan terhadap keberlangsungan Negara Kesatuan Republik Indonesia. Untuk mewujudkan hal tersebut maka Pendidikan menjadi peran utama dalam memajukan setiap langkah gerak Pemuda untuk menyongsong hari yang lebih baik dan menjadi berguna dalam bekehidupan Berbangsa dan Bernegara. Pembahasan Manipol Usdek sangat penting untuk membuka cakrawala cara berpikir kritis terhadap pemuda sebagai penerus Bangsa yang sering disebut sebagai generasi Milineal. Budaya Nusantara Bangsa Indonesia harus terus dijaga untuk menunjukan bahwa Generasi Muda masih mampu untuk mempertahankan Budayadan Adat disertai Agama yang dianut dengan memberikan pendidikan yang yang sesuai dengan karater Bangsa. Banyak hal yang bisa dilakukan Pemuda dalam bidang pendidikan dengan mengikuti event atau kegiatan yang bersifat akademis untuk memberikan kontribusi kepada Negara agar bisa bersaing di kancah internasional dengan menjadi juara-juara di bidang sains. Manipol Usdek bisa menjadi panduan terhadap prilaku Pemuda Indonesia dan menjadi karakter bulding dalam menyongsong Bonus Demografi Dunia dalam mengahdapi persaingan untuk menunjukan Negara Indonesia adalah Negara yang besar dan mempunyai caloncalon pemimpin Bangsa.

\section{PENUTUP}

1. Kesimpulan

Berbagai upaya yang telah dilakukan oleh pemerintah dalam memberikan pelayanan dalam pendidikan untuk memejukan bangsa dan negara Indonesia dalam menghadapi situasi dan persaingan global akan tetapai masih banyak hal yang harus diperbaiki di segala bidang, untuk itu perlu peran serta masyarakat dalam membangun bangsa dan negara ini dari ketertinggalan agar bangsa Indonesia bisa bersaing dalam menentukan nasib masyarakatnya. Sebagai seorang pemimpin the founding father kita Bapak Ir. Soekarno sudah meletakan batu pertama dalam pembangunan sebagai pondasi masyarakat Indonesia mengerti akan sejarah dalam perjuangan membangun bangsa dan negara, selanjutnya para generasi penerus harus lebih kokoh dalam 
membangun bangsa sehingga menjadi satu kesatuan dalam pembangunan dan tidak akan keropos ketika sudah berjalan ditengah-tengah dan menjadikan bangunan itu runtuh. Peran serta masyarakat dalam membangun bangsa dan negara ini sangatlah signifikan untuk menjadi contoh peradaban bangsa yang besar dengan kemajemukan yang dimiliki melalui dunia pendidikan. Dengan memberikan pendidikan yang terbaik buat generasi penerus kita maka bangsa dan negara Indonesia akan menjadi negara yang kuat dan kokoh disegala bidang untuk menjadikan Negara Indonesia yang makmur, sejahtera, aman dan tentram.

2. Saran

Perkembangan dunia pendidikan sekarang ini sangatlah komplek sehingga perlu pembelajaran yang bukan hanya sebagai peningkatan keilumuan saja akan tetapi perlu juga banyak pengalaman lapangan dalam menyelesaikan beberapa masalah yang dihadapi oleh masyarakat Indonesia khususnya di bidang pendidikan sehingga masalah-masalah pembelajaran menjadi isue yang bisa didiskusikan dan dipecahkan bersama melalui diskusi dan demokrasi dalam mencapai kesempatan olah pikir dari semua lapisan masyarakat untuk mengembangkan jati diri rakyat Indonesia. Saran untuk pemegang kebijakan agar terus melakukan inovasi tentang pendidikan melalui berpikir manipol USDEK yang menjadi konsep dari bung Karno dalam membangun bangsa Indonesia pada jaman kemerdekaan. Semoga yang dicita-citakan oleh para penjuang kemerdekaan bangsa Indonesia dapat menjadi jalan menuju yang lebih baik untuk menggapai impian negara kita menjadi negara yang tangguh dalam segala bidang.

\section{DAFTAR PUSTAKA}

Arif Yusuf Hamali, Eka Sari Budihastuti, Yulia Listianti. 2019. Pemahaman Administrasi, Organisasi, dan Manajemen, Yogyakarta. Penerbit CAPS. ISBN: 978-602-9324-89-1.

Ibnu Parna. 1959. Di Bawah Panji Marxisme Aliran Lenin dan Trotsky, Jakarta. Penerbit Yayasan Pekerdja.

Ma'ruf Cahyono. 2019. Bahan Tayang Materi Sosialisasi Empat Pilar MPR RI, Jakarta. Sekretaris Jenderal MPR RI.

Ratminingsih, Ni Made. 2019. Pengajaran, Karakter, dan Cinta. Singaraja, Bali. Penerbit Mahima Institute Indonesia. ISBN: 978-623-7220-

09-1

Pasek Suardika. 2011. Bung Karno \& SBY Dua Presiden Pertama Indonesia. Bali. Penerbit Bali Aga. ISBN: 978979-26-3222-4.

S. Aminah, Roikan. 2019. Pengantar Metode Penelitian Kualitatif Ilmu Politik. Jakarta Timur. Penerbit Prenadamedia Group. ISBN: 978602-422-751-7.

Sugiyono. 2010. Metode Penelitian Pendidikan. Bandung. Penerbit Alfabeta 